Culture \& History Digital Journal 8(1)

June 2019, e011

ISSN 2253-797X

doi: https://doi.org/10.3989/chdj.2019.011

\title{
Women of Salamanca. Academia, society and culture
}

\author{
Virginia Ávila García \\ Universidad Nacional Autónoma de México. Facultad de Filosofía y Letras. Dirección General de Asuntos del Personal Académico. \\ Escalinatas 56, Colonia Jardines del Sur, Delegación Xochimilco, Ciudad de México, c.p 16050 \\ e-mail: viquiavilag@yahoo.com.mx \\ ORCID iD: https://orcid.org/0000-0002-7319-6468
}

Submitted: 22 January 2018. Accepted: 12 November 2018

\begin{abstract}
This research was carried out during a 2017 sabbatical spent at the University of Salamanca. My objectives were to recover the historical memory of the early figures of the feminist struggle in that university and its context in the years of Spain's transition to democracy, elucidate the processes through which women sought institutional empowerment over almost four decades, and explain the diverse interests that converged in different ways to understand women's rights and the integral insertion of women into domains of academic and social life.

The study had two axes: first, to ascertain the convergence-divergence of interests among Salamancan women from the 1960 s to 1990 s, especially between two groups of militants, one social, the other academic, where the variables of social class and professional formation became apparent; and, second, to reconstruct the paths that women professors took to improve their status and gain recognition for their contributions to science in Spain's oldest and most conservative university, by creating a Centre for Women's Studies (Cemusa) at the dawn of the new century. The methodology involved rescuing the voices of women citizens, housewives and long-serving professors who narrated their lives as social fighters. The review of documents, pamphlets, photographs, videos and the collection of Cemusa's publications facilitated recreating the life of Salamanca, its university and its women.
\end{abstract}

KEYWORDS: Professors; Feminisms; Centre for Women's Studies; Salamanca; Cemusa; Society of Knowledge; Salamancan women.

Citation / Cómo citar este artículo: Ávila García, Virginia (2019) "Women of Salamanca. Academia, society and culture" Culture \& History Digital Journal, 8 (1): e011. https://doi.org/10.3989/chdj.2019.011

RESUMEN: Mujeres de Salamanca. Academia, sociedad y cultura.- Este trabajo de investigación fue realizado durante una estancia sabática en 2017 en la Universidad de Salamanca y tuvo como objetivos: recuperar la memoria histórica de las pioneras protagonistas de la lucha feminista en esta ciudad durante los años de la transición democrática en España; clarificar los procesos femeninos para empoderarse institucionalmente en la Universidad a lo largo de casi cuatro décadas y explicar la diversidad de intereses que confluyen en las diferentes formas de comprender los derechos y la inserción integral de las mujeres en los campos de la vida académica y social.

Los ejes de la investigación fueron dos: buscar la confluencia-divergencia de intereses de las mujeres salmantinas entre las décadas de los años setenta a noventa, particularmente entre militantes sociales y académicas donde se advierten ya las variables de la clase social y de formación profesional; el segundo eje reconstruye el camino de las mujeres académicas por alcanzar un status de reconocimiento a sus aportaciones científicas en la más antigua y conservadora universidad española, mediante la creación del centro de estudios de las mujeres a principios del siglo naciente. La metodología se sustentó en la recuperación de voces de mujeres ciudadanas, amas de casa y de académicas de larga trayectoria mediante sus relatos de vida como luchadoras sociales. El manejo de documentos, panfletos, fotos, videos y el acervo creado por las publicaciones del Cemusa facilitaron la recreación de la vida salmantina, de su universidad y de sus mujeres.

PALABRAS CLAVE: Académicas; Feminismos; Centro de Estudios de la Mujer; Salamanca; Cemusa; Sociedad del conocimiento; Salmantinas.

Copyright: (C) 2019 CSIC. This is an open-access article distributed under the terms of the Creative Commons Attribution 4.0 International (CC BY 4.0) License. 


\section{INTRODUCTION}

Salamancan women born during Franco's dictatorship participated in the transition to democracy in contemporary Spain. These were professional women who entered the society of knowledge from the late 1960s onwards in a historical process that opened the way to a worldwide reconfiguration of the neoliberal model of globalization into which they were incorporated. Empowerment of Salamancan women began with their participation in social movements that steadily created their own agency, which later diversified to attend to the interests and needs of different women's groups, sparking internal struggles over the creation of spaces of power. The resulting disagreements and ruptures impeded establishing collaboration and non-aggression pacts among women.

This history of women scholars in Salamanca traces the process of the internal formation of feminist groups and their fractures, before focusing on their institutional recognition and creation of their Centre for Women's Studies (Centro de Estudios de Mujeres, or Cemusa) at the University, where they sought to enrich the society of knowledge with their contributions.

\section{SALMANTINAS IN REBELLION}

Our history begins in Salamanca in 1978, at the height of the Spanish mobilization over the country's reconstruction after the death of the dictator Francisco Franco, in 1975. The Salamancan Feminist Group (Grupo feminista de Salamanca), founded by university students and professors, rebelled and supported the demands of housewives organized in neighbourhood associations. Together, they delineated feminist demands, participated in politics, and gathered with their affiliates to discuss the importance of their vote on the referendum convoked on Spain's new Constitution. This "Group became radicalized and emitted a negative vote [refusing the new Constitution], having reached the conclusion that the proposed laws were insufficient to improve women's living conditions. ${ }^{2 \text { " }}$

One of the Group's founders was Antonia Díez Balda (interviews with Antonia Díez Balda, June 2017), a militant in the Revolutionary Communist League (Liga Comunista Revolucionaria), social activist, and professor at the University of Salamanca. Her personal history was indelibly marked by the figure of her strong-willed mother who, widowed while still young, had to confront the social conditionings that the dictatorship imposed on women, but emerged triumphant. Díez Balda commented that her mother pushed her to study geology at the University (Díez, 1986). Her family life sensitized her towards feminism and her socialist leanings were marked by a yearning to change the world. In March 1973, she and her husband went to Chile, following their dream to participate in efforts to consolidate President Salvador Allende' peaceful path towards socialism. While there, the young couple was hired by the Universidad de Concepción, where they were active in both academic and po- litical life. Antonia and her husband, also a geologist, experienced firsthand the coup d'état perpetrated by troops under the command of Augusto Pinochet in September 1973, and had to flee to Ecuador. Two years later, they returned to Spain, where the University of Salamanca hired him as an assistant professor and offered Antonia a fellowship. Later, she became a professor and began her long academic trajectory that culminated with her retirement a few years ago.

Early on, Antonia devoted her energies to activities that fostered the formation of groups that would lead the fight for social rights while also working to organize salmantinas to campaign for equal rights with men. Thus, she was a pioneer feminist in both the University and wider Salamancan society (Díez, 2002:257-258). In October 1979, she and a group of friends from the university led a solidarity demonstration in support of ten women and a man who had been arrested in Bilbao accused of practicing abortions or caring for women who had aborted. The ranks of that manifestation swelled when women from Neighbourhood Associations, the Communist Party and other solidarity groups in Salamanca joined in. Díez sustained (in the interview cited above) that this show of solidarity marked the beginning of a consistent feminist struggle in her city:

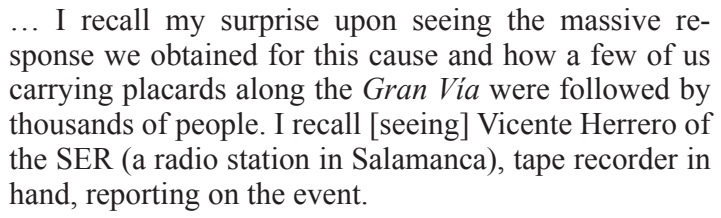

One of the housewives and militants of the Communist Party who joined the demonstration that set out from the Plaza Mayor of Salamanca en route to the Gran Via, was María de los Ángeles Corrochano Cosmea, ${ }^{3}$ affectionately known as Nines. She sees that protest as the key moment that united diverse groups of Salamancan women with other social movements (interviews with Nines, June-November 2017). In the wake of that event, the Feminist Group of Salamanca forged linkages with women of diverse social condition and soon became the Assembly of Salamancan Women (Asamblea de Mujeres de Salamanca), which met Monday evenings at 8:30 at a locale of the Union of Women Workers' Commissions (Sindicato de las Comisiones Obreras). Attendees included young scholars and university students from Salamanca, as well as housewives convoked by the Neighbourhood Associations that, Nines recalls, ${ }^{4}$ formed in 1974 to respond to the specific needs of housewives and their families, defend their right to work, reject unemployment, obtain better sanitary services -including the right to family planning- and participate politically, as outlined in a Communist Party document and by the Workers' Commissions: ${ }^{5}$

The feminist movement has a specific and important role to play by raising women's awareness of the aspects that reveal how they are discriminated against in 
the economy and work, and by promoting, from their optic, the corresponding vindications, not only in the general aspect of the right to work and opposition to woman's unemployment, but also in the face of concrete problems of part-time work, the timely propagation of the return to the home, and the high estimation of the role of the housewife, the union of housewives, etcetera.

The Communist Party also stimulated members like Dr. Angelita San Francisco and Aurelia a director of the Coordination of Neighbourhood Associations (Coordinadora de Asociaciones de Vecinos), and Nines, to solidify links with neighbourhood struggles. Nines said that some priests associated with Liberation Theology who had served in the Americas also participated, mentioning specifically the parish priests Antonio and José (whose surnames escape her), who from 1974 onwards, guided the creation of mutual support groups that worked to improve conditions in poor communities with the active participation of many women.

Nines' trajectory of social militance continues to the time of the interview, at the age of 83 . Her social conscience was potentiated by a difficult childhood that began in exile in Morocco, where her family took refuge because her father, the republican pilot José Corrochano, was being fiercely persecuted. She wore her communist and atheist profile with pride as her father's legacy; a republican soldier who was imprisoned and sentenced to death on three occasions. His example had an enormous influence on the formation of Nines' committed character, though she also noted the influence of her mother and grandmother, the latter a schoolteacher who struggled hard to survive in Tangier.

Upon her return to Spain, now married and with children, Nines confronted the social resistance to change that loomed, for the model of the role of women in Salamanca never changed under the Republic (Tavera, 2007:239); a "conservative, essentially resigned, society loaded with virtually-closed vital essences that were conveyed to the social milieu" (Francia, 2002:14). She stated that the goal of contemporary women in the 1970s was to stay at their "husband's side" though others, including her, yearned for opening horizons.

University professors and housewives in the Assembly coincided in arguing that it was urgent to train women and sensitize doctors and authorities in fields like family planning and the use of anti-conceptives ${ }^{6}$; a struggle they won, but not until 1981. Opposition to their efforts poured in from all sides, including the fachas; her word to refer to conservative men and women with fascist tendencies who sympathized with the dictatorship. Nines observed:

... some of us went, very well-dressed, to visit Dr. Ángel García, a prestigious gynaecologist and professor at the University of Salamanca. He received us amiably due to our lovely appearance, but quickly dismissed us upon learning the motive of our visit: to request a locale and medical personnel to orient Salamancan women about reproduction. He responded - clearly angeredthat only doctors could decide for whom they would prescribe anti-conceptives, and that it could only be for married couples, [since] the husband's consent was indispensable.

The creativity of the Women's Assembly was evident, especially among the professors, in the diverse strategies they adopted to publicize their actions, including weekly meetings, demonstrations, appearances on radio programs ${ }^{7}$, and manning a stand in the Plaza del Corrillo near the Plaza Mayor de Salamanca, where Sundays found then selling books on women's issues from a table and offering advice to anyone who wished to consult them on the problems of daughters who were working as prostitutes, or who wanted information on birth control or abortion (Díez, 2002). Occasionally, they gave women money so they could go to Belgium for abortions. This solidary support of feminists spread to other groups, as like some young Catholic students who gave their friends money for travel and other expenses to enable them to go to France for abortions (testimony of a female entrepreneur in Salamanca, September 2017). ${ }^{8}$

As time passed, women from the Assembly separated to focus on the problems of their class, as those from poor neighbourhoods turned their attention to resolving immediate problems: obtaining day-care and potable water, paving streets, and creating gardens, recreational spaces and health centres; in short, a whole series of basic services necessary for the wellbeing of families, women and communities, as Nines said. The students and professors, meanwhile, worked to define studies and lines of research on women while also fomenting academic feminism. Nines reflected on this aspect in our interview:

... they were young, single, university women; I was divorced, other friends were married; all of them intelligent, but with distinct intelligences. We yearned for our daughters to study careers and become professionals. We left the Assembly because, while they were stupendous, they only discussed lesbianism, abortion, divorce, and [argued] that women should be able to do whatever they want with their bodies [but] as women from neighbourhoods we were fighting for other things.

Housewives met with women professors in the Assembly from 1979 onwards, understanding that they had shared interests as women in achieving social, sexual and reproductive rights, though each group's social and educational characteristics led them to prioritize their own needs and interests (Ávila, 2015:480).

\section{UNIVERSITY AND SOCIETY}

The university professors in the Women's Assembly, including Antonia Díez Balda, Carmen Castrillo, Rosario Cortés and María José Cantó, defined demands for the women of their class in their studies, but their theoretical discussions distanced them from the concrete problems of housewives, so some -though not Antonia- left social feminism to join the nascent academic feminist movement, which outlined the themes of their militancy and 
began to prepare them to "occupy their own space" in academia. In Consuelo Flecha words' (2014:53), they were the pioneers of feminism in Spain's universities:

Opportunities intensified, doubtless due to the advent of democracy [and] thanks to an active raising of consciousness by these women, their diligence in striving to attain goals that, not for the first time, vindicated the desire to freely enjoy new lifestyles. By criticizing the imposed conditions and denouncing obvious inequalities, these feminist movements provided the humus from which sprouted more ambitious personal expectations and collective projects among our young women.

In the $1980 \mathrm{~s}$, the rights of women and men were declared juridically equal. Women no longer required marital licenses and could vote and manage their own resources. Divorce and anti-conceptives were allowed, and family planning was accepted. From that time on, Spain's feminists, who had lagged behind other Europeans -and perhaps had less discursive baggage (Cuesta 2002:32)accelerated their pace to achieve parity with international feminist movements, while assimilating the international agenda.

In those years, discussions among European women revolved around three issues: the feminism of equality $v s$. the feminism of difference; double vs. single militancy, and radical vs. socialist currents (Folguera, 2006:439). Most of Spain's feminists identified with the feminism of equality that the Spanish philosophers Celia Amorós and Amelia Valcárcel developed as theoreticians who would be widely-read in Spain and America. However, as we will see, feminism in Salamanca was marked by conflicting positions that generated publications in both currents. Some pioneering feminists, like the Salamancan philosopher of feminist critical theory, Teresa López de la Vieja, and the philologist Mercedes Romero, defended the feminism of difference, but most militant feminists defended the feminism of equality.

From its founding, the Women's Assembly manifested double militancy by participating in both political parties (mainly communist and socialist) and women's organizations. The influence of the communist women who had led resistance to the dictatorship declined, and political participation was seen with distrust by the feminists who were demanding women's rights in gender relations and the struggle for power. Soledad Murillo, the feminist sociologist from Madrid working at the University of Salamanca, put it this way: "women tend to define themselves by their political party and relegate feminism in their everyday decision-making, because the political commitment is often more demanding. ${ }^{9} "$

This discussion often arose in feminist organizations, especially among women in communist parties whose priority was to bring about the social change to obtain a scenario of equality where women could fully enjoy their rights. Those who stressed the struggles for women's rights drew the contours of international feminism. Also, a process of historical decontextualizing began that, in some currents of feminism, isolated feminist struggles in favour of a militancy that sought to conquer broader, emerging rights. Thus, the struggle became radicalized by aligning itself with social struggle. It is in this space that we detect a lack of analytical objectivity which biased a form of militancy with historical relativism.

The hopeful, vital mobilization of preceding years continued into the 1980s, but lost some strength, and soon the rapid advances of the transitional years of 1975-1985 demobilized Spanish society as it turned its attention to the tasks of democratically erecting a new society, one that sought to reinsert itself into European history bearing the baggage accumulated in that period. The inequities of a democracy under construction in the context of a capitalism entering the neoliberal phase obliged feminists to insist in demands like equal pay for equal work by men and women and defining parity and quotas of political participation as tools for achieving equality (Valcárcel, 2006).

These Salamancan women focused on their professional careers and pursued their own goals. While some groups persevered, efforts by the pioneer Antonia Díez Balda were now limited narrowly to her work of teaching students, striving to maintain awareness of the emblematic dates of the feminist struggle, and offering support to other movements. She remained very active until $1986^{10}$, and still in the 1990s answered the call of feminist academia with Soledad Murillo. Even today, in retirement, she maintains her social and feminist militance, though her direct links to other women largely dissolved with the emergence of academic feminism.

\section{DEBATES IN ACADEMIA}

In 1993, Soledad Murillo defended her doctoral thesis in sociology entitled, "The sexual division of public, private and domestic spaces"11 at the Universidad Complutense de Madrid. A pioneering study in the field, her work revealed the differences among those three spaces, how domesticity shrouded the lack of private and public spaces for women, and how men appropriated both their own times and those of women. The interrelation of these three spaces supported her hypothesis concerning the difficulties of professional development and the absence of personal female spaces that women could enjoy freely.

Murillo's feminist formation was already forged when she arrived at the University of Salamanca as a professor in 1993. In our interview (August 2017), she commented that she had taken a post-doctoral course on "Feminism and the Enlightenment" that strengthened her theoretically, and had also collaborated with the psychiatrist Carmen Sáez in the Gregorio Marañón Hospital in Madrid for two years. Sáez devoted her practice to attending to women diagnosed with mental imbalances using a novel erotic-affective approach that revealed the particularities of feminine identity. Murillo observed that Sáez work was characterized by a 'turn' that led her to treat her patients as subjects distinct from men. The years spent with Sáez led Murillo to state that she had exerted a determining influence on both her professional life and her feminist mil- 
itance. Murillo's trajectory was further enriched by her work in the women's bookstore and her participation in the Feminist Movement in Madrid, and when she came to the University of Salamanca as an interim professor she also had experience in entrepreneurship.

Murillo arrived to work on a project of the Women's Institute with a budget of $\$ 15,000$. In 1995, her theoretical-militant formation propelled her to create an NGO called "Women's Studies Seminar of the University of Salamanca" -later known simply as the "Women's Studies Seminar"- which ran from 1997 to 2009. This initiative spurred efforts by female scholars to wrest political power from the male monopoly that had secured it since the institution's founding in 1218. Cristina Borderías (2009:12-13) theorized women's transgressions -like those examined herein- by stating: "we need to analyze deeply the forms, mechanisms and processes through which those partial (or individual) transgressions were inserted into a process of collective (or global) change of power relations", and then asking: how are we to conjugate the exclusion of women from forms of political action with the forms of female agency that are being identified?

Through acts of female empowerment in universities, like creating the Seminar, Salamancan women scholars also came to question scientific knowledge as it was constructed and taught in the institution's programs, because it ignored female actors and their contributions. The consequences of these reflections that shaped the Seminar were immediate: the militancy of women professors was reinvigorated and they turned their energies to institutionalizing critical thought, following Soledad Murillo's lead. She approached women pioneers like Antonia Díez and the Mercedes Romero with a proposal to organize a Permanent Seminar on Women's Studies, an open forum that would encourage dialogue with all classes of women who showed interest. Though Murillo's democratic vision of a Seminar directed by university professors but linked to the wider society and the community of Salamancan women was never realized, it did trigger an intense, strained debate among professors who perceived the internal differences and divisions in the groups that were struggling for power.

The historian María Esther Martínez Quinteiro observed that the women professors behind the Seminar wanted to organize it inside the university as a step towards formalizing studies of this kind. But differences in focus caused frictions among its organizers, almost from the outset: "There was much debate over how to conduct the interdisciplinary study of gender" (interview with Martínez, November 2017). When the Seminar debuted in $1995,{ }^{12}$ it was linked to the University, but not formally recognized by it. The decision to call it a Non-Governmental Organization was seen as a stepping-stone to the goal of institutionalizing women's studies at this conservative university that resisted opening spaces for women.

The Seminar's topics and theoretical discussions were led by Murillo with the support of Mercedes Romero, who held a Master's degree in Women' Studies from the
Universidad Central de Barcelona (1991), and who gave courses on critical feminist theory to a group of some fifteen women at the university, including the professors Carmen Castrillo, María José Cantó and Rosario Cortés, and several doctoral students (telephone interview with Mercedes Romero, November 2017). Also affiliated with the Seminar were historians like María Esther Martínez Quinteiro, Ana Díaz Medina and Josefina Cuesta, while participants included professors and students from several departments, especially historians, sociologists and other social scientists. However, as more professors joined, it became increasingly difficult to reach agreements on the Seminar's methodological orientation and the issue of choosing its president. After the period under Murillo, women broke away to form discussion groups in their individual fields of study, which meant that the goal of sustaining an interdisciplinary seminar with a clear, solid direction ceased to be feasible. These divisions are still evident today among working groups that establish lines of research which reflect the specific interests of distinct disciplines, thus setting aside interdisciplinarity. This can be explained by the fact that some participants had succeeded in occupying spaces of power in their own disciplines, but also by the structure of study programs and the strict forms of curricular evaluation at the University that scarcely valued or recognized multi- or interdisciplinarity; a trait shared by many traditional universities.

Among the Seminar's study groups, one line of research stands out: the history of women, but even it was not explicitly linked to the field of gender studies that, by the 1990s was being consolidated at Spanish universities in Barcelona, Madrid, Granada and Valencia. Thus, Salamanca continued to lag behind.

Female Law and History professors gradually came to form the majority in the Seminar through a process which meant that other fields were somewhat relegated. By the late 1990s, historians were effectively setting the Seminar's course, because they perceived history as a useful tool for achieving equality and increasing the visibility of women's contributions in all fields of knowledge and all periods. In taking this direction they distanced themselves -opportunely- from the contemporary struggles of the other women.

Female law professors, meanwhile, organized research groups on topics of jurisprudence that have enjoyed continuous growth and reinforcement. They are now seen as having long trajectories after designing their own fields of study. In both the university and the public sphere, this juridical orientation has met with growing acceptance due to the emphasis that those scholars place on legislation concerning women's rights and their great impact on public policies. The perspective of these law professors stressed the need to increase knowledge of the laws, while the women historians highlighted the role of female subjects in the diverse social and historical contexts where gender inequality existed.

After a long period of discussions and contributions to knowledge, and well aware of the importance of institutionalizing the Women's Studies Seminar, the feminists 
led by Murillo began negotiations to form an Institute of Women's Studies at the University. Despite their many years of diligent work and production of extensive scientific knowledge, their proposal was rejected by both the University's collegial organs and Rectory. Amidst diverse academic groups, Murillo decided to resign as Director of the Seminar, but she soon found herself totally marginalized from the project - the Seminar- that she had created. In one interview, she said that she was blindsided upon learning that she was "not invited to any academic activity related to the Centre for Women's Studies from its creation until recently, in March 2017" (Murillo:August 2017).

Through her experience as professor and activist, and her academic efforts to train groups of women to hold positions of institutional power and obtain rights and recognition for women, Murillo had come to know, first-hand, the threads of power woven between male and female academics and their relation to the institution's decisionmaking organs. She once characterized the University as just another public space where power is disputed, one where "I learned to swim in a shark-infested sea". But all these experiences helped her make informed decisions during her later work as a member of President José Luis Zapatero's cabinet, where she served as the first Minister of Equality (Secretaria de Igualdad), sponsored the Law of Equality (3/2007), and helped establish equality committees in Spain's universities that sought to: "Ensure that the University obeyed legislation on the effective equality of women and men, and promoted and enforced equal rights", as established in Article 177 bis. 1 of the Statutes of the University of Salamanca. ${ }^{13}$ According to Murillo, the equality committees constituted an additional administrative burden, one that did not fulfil its functions but did present awards to individuals who stood out in the struggle to achieve equality between women and men in academics at the University.

\section{A SPACE OF POWER FOR THE FEMENIST ACADEMIA}

The efforts of those female professors to attain recognition for women's studies was supported by their contributions to scientific knowledge and the diligence with which feminist scholars there pursued the development of a disciplinary field based on the theoretical and practical foundations of a Seminar that aspired to earn the status of a research institute. As a special interest group, these women faced a whole series of institutional pressures and privileges that resisted their formation as a field of study inside the University. This confirms Michel de Certeau's observation that, "Each discipline is, at the same time, the law of one group and the law of scientific investigation". In this effort to achieve consolidation as a scientific discipline, the contributions of feminist studies to science lacked the force that comes with being directors or having erudite personnel; that is, those who monopolize classes and positions represented by the university's hierarchies. Attaining disciplinary consistency would require reinforcements.
The women who promoted this change lacked the powerful voices that would have propitiated acceptance of the Institute among academic power groups in the setting of a male-dominated ideology that lacked neutrality (or objectivity), and so was unable to consider the importance of these studies by, and about, women. Up to then, the University's governing bodies, comprised mostly of men, had tolerated or simply ignored these feminists, so when they began to seek recognition their first attempts were firmly rebuffed.

Throughout this process of empowering women scholars, the groups forged in the Seminar suffered from the differences that caused tension inside the organization. One consequence of those disaccords was that some women broke away. In this process, the social and feminist militants who had trained theoretically under Murillo and were still closely-allied to her-like Mercedes Romero, Teresa López de la Vieja and Antonia Díez- drew away from the women professors who were pursuing official recognition and disdained socially-committed feminism. Meanwhile, the Seminar was attracting people who saw it simply as a novel space in the University to accumulate curriculum, as Soledad Murillo commented.

Women like María Esther Martínez Quinteiro who were familiar with the ins-and-outs of university power thought it advisable to lower expectations and propose creating a 'centre' instead of an 'institute'. That initiative was approved in 1999 and the Centre was inaugurated in 2002 (interview with Martínez Quinteiro, November 2017). The University's Statutes defined the Centre as one of four legal figures authorized to perform research; the other three were 'Institutes', 'Research teams', and 'Units of excellence'. Its first directors, ${ }^{14}$ however, had to cope with deficiencies that constrained its development, especially the lack of full-time academic personnel, scant financial resources, a skeleton administrative staff, and a rule that impeded members from prioritizing research and devoting most of their institutional time to it; in other words, research at the Centre took a backseat to the professors' teaching load.

In the story that concerns us, Martínez Quinteiro led the group of scholars that sought institutional recognition while marginalizing social militancy. She represented the professors who were empowered after Murillo's resignation and the withdrawal of other militants committed to the social struggle. Martínez is a skilled negotiator who, with other women historians, obtained for female professors in Salamanca "a room of their own". She managed the talks that, in 1998, convinced the Rector, Ignacio Verdugo, to authorize the Centre. The Negotiating Committee emphasized that the group had a productive academic experience in the Women's Studies Seminar and more than ten female professors with Doctorates who were recognized for their research (Reglamento, art 22). In fact, the proposal was backed by female scholars from the Faculties of Social Science, Law, Geography and History, Philosophy, Psychology, Philology, and Medicine and Pharmacology. After hearing their proposal, the University's Governing Council authorized the Centre's creation 
on November 25, 1999, though it did not commence formal activities until January 2002 (http://mujeres.usal.es). The Women's Studies Research Seminar, created a decade earlier, was subsumed by the Centre -known as Cemusa- and disappeared in 2009.

Ana Díaz Medina, ${ }^{15}$ a member close to the group that founded the Women's Studies Seminar and a professor in the Faculty of Geography and History (Department of Modern History), was named the Centre's Director by the Rector for the 2002-2006 period. She accepted the appointment. According to comments by María Esther Martínez, seconded by Soledad Murillo, Díaz "was a person with energy [and] strength who knew how to relate to the Rectory". These two women coincided in considering her a capable person and good negotiator who tried to reach consensus; a woman of firm character committed to feminist studies.

Ana Díaz Medina proceeded to reorganize the research groups and adroitly managed the Centre's $€ 5,000$ annual budget, including the publication of a journal collection and collective books, and the organization of a History Congress (Jornadas de historia) and other events. She obtained a small space for the Cemusa's offices and persuaded many feminists to collaborate. Her period in office was a dynamic one, marked by many projects that began to gain visibility for the professors' academic work in the institutional framework (interviews with Martínez, 2017). The Cemusa operated with a mixed professoriate ${ }^{16}$ that included people with feminist interests and others who joined to enhance their curriculum vitae (Murillo, August 2017). The University's regulations allowed the Centre to organize events, courses and research seminars, and to grant accreditation for those projects.

In this initial period of institutionalization as a separate Centre, the marginalized feminists regrouped but, once again, failed to reach accords. Thus, the law and history professors distanced themselves once again, now free of the hindrances of the historical or pioneering feminists whose strength had been diluted. When it came time to elect the Centre's new Director, the historian María Esther Martínez Quinteiro presented her candidacy to the Centre's administrative board. She won, was named Director for the 2006-2010 period and immediately named Angela Figueruelo, a law professor, as Sub-director. This allowed the historians and lawyers to create -conjointly in 2006- a Master's Program in gender studies and, in 2009, a Doctorate in the same field, both endorsed by the Faculty of Law.

Martínez Quinteiro forged links between the Centre and local and regional governments, while maintaining good relations with the University's governing bodies and a high profile for the Centre, thanks to her broad academic and administrative experience. She continued to publish the Cemusa's journal and consolidated the weekly program of "Radio Talks" (Tertulias radiofónicas) on $R a$ dio Usal which, ever since, has set aside one hour for discussions of topical issues of the local, regional, national and international feminist agenda.

During her time in office, six research groups continued to work in their respective fields of study, and the Ce- musa began to emerge as a space of institutional reference and inter-university relations, though no viable options for further growth appeared because, as she explained, Spain's 2008 economic crisis affected universities by substantially reducing the budgets of Centres deemed to be of 'low priority', like the Cemusa.

Director Martínez called elections for her successor as her mandate was ending and the date of her retirement approached (July 2014). Once again, the historians triumphed, as their candidate, Josefina Cuesta Bustillo, was elected as Director for the three-year period, 2014-2017 (interviews with Josefina Cuesta, April-December 2017). During her short time at the helm, Cuesta pursued Cemusa's main goal of converting the Centre into the Castilla y León Interdisciplinary Inter-university Gender Institute (Castilla y León Instituto Interuniversitario Interdisciplinar de Género), an ambitious project that proposed linkages among the Universities of Salamanca, Valladolid and León, the three principle cities in the autonomous region. She hoped to see the new Institute become the regional referent for creating knowledge on women and feminisms with a widely-recognized leadership role (Memoria, 2015:16, 45).

The technical team elaborated the proposal and an accompanying document: "Memory: The Process of the Creation/Ascription of University Research Institutes (Memoria. Proceso de creación/adscripción de institutos universitarios de investigación), which narrated the $\mathrm{Ce}$ musa's history and its production in the previous five years. It includes the curricula vitae of many members, identifies the international networks in which it participated, describes the make-up of its scientific committees, and records its prolific activity, including several publications and 26 graduate theses. But this proved insufficient, and the proposal failed due to a lack of support.

\section{FEMINIST CONTRIBUTIONS TO THE SOCIETY OF KNOWLEDGE}

Works by scholars at Cemusa constitute true contributions to the "society of knowledge"17 (Krüger, 2006) exemplified in two initiatives: first, the legislative work and lobbying to support ratification of the Law of Equality and, specifically, forming the Units of Equality for Universities ${ }^{18}$ promoted by the Secretariat of Equality that Soledad Murillo led from 2004 to 2008; and, second, the four-volume work, La historia de las mujeres en España (The History of Women in Spain), coordinated by Dr. Cuesta and published in 2003 by El Instituto de la Mujer. It was the result of a research project funded by that Instituto in which several of the Centre's women collaborated, including María Luisa Ibáñez Martínez, Ursula Martín Ascensio, Cristina García Nicolás, Rosa María Merino Hernández and María Esther Martínez. Other outstanding contributions were written by members of Cemusa but were not products of the Centre's own projects due to its scant financial resources. Thus, they were published by the University of Salamanca or some other university where the Centre's professors participated. ${ }^{19}$ 
One such outstanding scholar is the philosopher Teresa López de la Vieja de la Torre who was affiliated with the Cemusa and produced numerous works on the feminism of difference, the ethics and critique of feminism, the autonomy of reproduction, and bioethics. She is one of Cemusa's pioneers because she was present from the founding of the Women's Seminar, Cemusa's precursor. Like Soledad Murillo, she has a web page, is very active in networks, and has spent research periods in universities in Germany, the United States, Mexico and Costa Rica. She speaks several languages and is a professor and thesis director at the graduate level. Her work is current because from philosophy she analyzes ethical problems raised by our globalized world (López de la Vieja et al., 2006), while her contributions to the ethics of feminism argue for epistemological change in constructing knowledge to fully incorporate the female half of the human species. López de la Vieja offers an exemplary case of the double role of women scholars: as a professor of philosophy and a theoretician of feminism.

The valuable contributions to knowledge and public policy developed by Soledad Murillo and others under the auspices of Cemusa and similar centres in Spain have transformed national and regional realities. By empowering women and overcoming the traditions and mentalities of a centuries-old university and conservative society, these women academics travelled a path that has discretely improved the relations of equality of Salamancan society and its university. They have made consistent advances in the academic domain and learned a great deal along the way, while constructing methodological proposals to conduct studies with greater scholarly rigor that they have designed in such a way that they have earned scientific stature and recognition by their peers.

In the near future, this knowledge must come to better represent the interests and works of feminists who, in their interrelations, need to forge accords, learn from these forty years of experience, and resist fragmentation. If they succeed, they will be able to form power blocks capable of empowering academic spaces by introducing positive policies. The foundations of this sisterhood will be a set of clearly-defined goals and mechanisms that resolve minor differences in this group of female academics, all of whom are aware that they are privileged to have both significant theoretical baggage and important products of research. These are the bases that will allow a repositioning of women in the new society of knowledge, where the University of Salamanca has been a leader internationally, especially in fields in the Social Sciences and Humanities, thanks, in part, to the contributions of the women professors united in spaces like the Women's Studies Centre, and their participation in teaching that includes gender as a path of knowledge and transformation towards a more equal society.

The stature of these researchers was responsible for the quality and volume of research in the novel field of studies that they, once again, sought to consolidate in the form of a research institute in 2015. But the response was the postponement -or tacit rejection- of their proposal because the times were not propitious and the organs of power lacked the required political will. As a result, the women professors who built the Centre must continue with this, limited, option for institutionalization while working to eliminate all signs of weakness from their initiatives.

The philosopher Michel de Certeau (1993) has written that all knowledge created in educational and research institutions must comply with certain exigencies to be judged as such. It has to respond to current needs, obtain institutional consensus, and be recognized by academic peers. But earning status in academia entails travelling a long path, and the female scholars at the University of Salamanca discussed here have clearly suffered the travails entailed in efforts to change the ideas, customs and inertias of a model of university and gender that extends broadly through Spanish America, as well, sustained by marginalizing women, more through custom than legislation (Pavón, 2017:17)

These women took on the challenge of creating -with few visible elements- knowledge of their history to clear away the shadows along that road. Initially, their studies were constructed in what might be called an 'artisan' fashion, closely-linked to the requirements of social movements and experiences of collaborative actions with housewives, during the brief time they shared in the Women's Assembly. Later, they refined their methodological instruments in joint meetings and discussions in the setting of the Women's Studies Seminar, and began to specialize in the theories proposed by feminists like María Aurelia Capmany and, especially in Salamanca, Lidia Falcón, ${ }^{20}$ Judith Aztelarra, Mary Nash and María de los Ángeles Durán, or inspired by the exemplary lives of Clara Campoamor, María de Maeztu and María Telo, or the approaches of French, British and North American feminists. They also recognized $20^{\text {th }}$-century pioneers of feminist thought, such as Concepción Arenal and Emilia Pardo Bazán.

The ruptures over double militancy, and the severe distancing they caused between the feminists who chose to prioritize social struggles and those who opted to set aside militancy and attend university to specialize in constructing related knowledge, molded the academic feminism characteristic of the 1990s, as occurred in other universities as well (Ávila: 2012). In this way, university groups and seminars centering on women that had forged their ideological and epistemological bases amidst social movements, separated from female academics who sought institutional recognition and spaces to create, and then reflect on, their objects/subjects of study, far removed from the postures of left-wing political militancy (Folguera, 2006:440).

These feminist academics predominated over those who continued their social militancy. Their epistemological corpus produced broad knowledge on women and their activities in the private world and daily life, but also revealed public spaces that were no longer occupied exclusively by men, but had certain niches that could be inhabited by these recently dusted-off women, and by his- 
torical sources that identified new -female- actors in history, law and science in general. This constituted a movement for women's equality, at the same time as a series of studies and reports were published in books and articles that enriched the society of knowledge. These female professors, finally, explored their powers in constructing the society of knowledge and visualized their path as women in teaching, letters and social movements capable of creating academic spaces for them. As Consuelo Flecha wrote (2014:51) "... for many women, education and access to knowledge meant a boost to taking distance from the mandates of gender, and were fundamental to the transgressive behaviours of many women during the $20^{\text {th }}$ century".

The vanguard women at Spain's prestigious universities designed methodological and conceptual tools appropriate for this new knowledge, and categories, concepts and theoretical corpus elaborated by women philosophers, sociologists, anthropologists and historians emerged. They also devoted time and effort to the task of theorizing in order to construct the disciplinary field of women's studies. Their goal was to support this epistemologically and so open spaces in science that would allow their studies to win recognition as true knowledge, while simultaneously battling in the halls of university power by consolidating interest groups.

Postures towards women's studies diversified, causing tension in theoretical discussions on the meanings of feminisms. Some scholars have been defined by women's studies quite apart from political positionings, focusing their research on women's contributions to various fields of science, social life, the workplace, and the family, using traditional methodologies of the Social and Human Sciences. Feminist studies, in contrast, seek to change female spaces; that is, to transform the unequal world in which human relations develop at all levels, from personal to public, based on the specific knowledge produced by female scholars. Both approaches have enriched this field in construction. Feminist and gender studies are also distinguished because the former seek to vindicate women's rights, but are often weak in terms of the social frameworks in which male-female relations unfold in the tasks of social life (Folguera, 2006:433); while the latter visualize the unequal conditions that affect women in an ongoing dialogue with relations with men, and clarify the social and historical scenarios in which analyses of those relations are situated.

Studies of female academics recognize them as social actors who emerge in scenarios that increasingly propitiate their professional development, because social conditionings require this. The tools of juridical equality though insufficient- must potentiate their functioning to open additional spaces towards equality.

The periodicity of the studies carried out by women scholars in Salamanca is broad, and they span almost all scientific disciplines in an effort to transversalize the concept of gender in approaches to research. In this way, they present disaggregated information on women and, in the best cases, construct solid argumentations concerning contemporary theories in the Social and Human Sciences. The epistemological commitment of these salmantinas recognizes that a long road lies ahead before people will be able to fully exercise their human rights in a world of equal and harmonious relations, and that universities form an integral part of that journey.

\section{FINAL THOUGHTS}

Militancy is a noun that scares the classes in power, including elite academic groups. The certainty in the belief that science is objective has not been transgressed, but was widely discussed in the past century. Therefore, feminist studies had to distance themselves from double militancy to avoid the appearance of politicization. This situation of academic asepsis is paradoxical, for it produces a discourse and posture that are discrete or open to the vindicating feminism that strives to balance the powers between women and men, while in relation to empowered groups of scholars and science who wield consensus-making power and reject or accept the knowledge created, the aim is to maintain an image of the women professor who is neither politicized nor actualized theoretically, much less committed with others of their class, but that adheres to institutional projects for feminist studies (Murillo, August 2017).

The Centre for Women's Studies at the University of Salamanca was a product of a historical process of forty years' duration. In constructing it, women professors responded to social challenges and those of their class. The early 1970s were propitious for social movements, as the dictatorship came to its end, allowing the social gears to be oiled so that Spanish society as a whole, and Spanish women specifically, could blaze paths to vindicate their rights and achieve better juridical and social conditions that would make up the ground lost, compared to women's movement in other western countries. Moreover, the coincidence of grand technological advances, nascent economic globalization, and women's liberation reveals the margins from which feminist demands emerged with their definitive incorporation into productive sectors and a public domain that demanded a loosening of patriarchal bonds.

Without doubt, the Salamancan women who undertook university studies were privileged historically, for they lived through the dictatorship, the ensuing transition and the phase of democracy in Spain. So many social changes stimulated their analytical thought and the women's revolution triumphed, accelerating Spanish democracy. To the quantitative changes we must add a huge qualitative leap; namely, the configuration of the European Union, which admitted the recently-established democracy as a member and played a defining role in Spain's consolidation as a nation that has learned to mesh with European modernity in the current phase of globalization.

The pioneering feminists in Salamanca-Antonia Díez Balda, Mercedes Romero, Carmen Castrillo, Teresa López de la Vieja, Josefina Cuesta, María Esther Martínez, 
Ana Díaz and Soledad Murillo, among others- transgressed the social order in Salamanca and its university by pressing for change. They lived and analyzed their personal, family, school and social lives and rejected gender inequality. These women belong to the privileged generation that suffered under a dictatorship, experienced a revolution that freed them from the corset of Francoism, and then lived in the light of the hopes of a democracy-imperfect but still, at long last, a democracy- in a world globalized by advances in technology, communications and the unstoppable march of science.

The gender models of men and women alike had deep ruptures in all aspects. The actions taken with other, less fortunate, women limited socially to their roles as wives and mothers, like Nines, Angelita and Aurelia, permitted a dialogue and clarity for understanding their historical moment and for denouncing in their circles their disgust with subjection, while at the same time differentiating among the various subordinations and scenarios in which women live socially.

The women that figure in this history acted from society and academia. They faced conflicts and differences of class due to the conditions of education, modes of living, marital status, family, and political commitments. These female professors led the construction of a space for gender interrelations that has clearly advanced, though there is much left to do. Today, Spanish society seems to be moving slowly, but is accepting the new models of autonomous, professional women. Indeed, one can see men participating more in the care of children and the elderly, though the gap between men and women in their freedom to manage their personal time still penalizes the latter. However, as Joan Manuel Serrat sings, 'trails are made by walking' (se va haciendo camino al andar).

Despite the restrictions imposed on the Centre, its marginalization from the wider university community, its weak links to the academic bodies of the fourteen faculties, and its isolation from the institutional interests of its governing organs, the Centre for Women's Studies at the University of Salamanca maintained its vitality as the setting whence women have constructed, and continue to construct, knowledge on female actors in the contemporary mobilizations that they visualize in their various activities, and propitiated the emergence of a discipline still under construction but committed to consolidating its institutionalization and academization.

The protagonists of this history have struggled to establish specific courses on the history of women and feminisms in their faculties, and to have the concept of gender included in courses in various study programs. Unfortunately, their quantitative advances are not reflected in a powerful assessment and approval because their attempts to earn institutional recognition have not overcome barriers that seem as stolid as the ancient buildings of medieval-Roman Salamanca. In fact, their efforts were stalled, once again, in 2012, when the Centre's study program was modified in accordance with the Plan Bolonia, and they failed in negotiations to have their studies included in the mainstream curriculum (Martínez, 2017).
Cemusa's directors have moved in many directions to increase the Centre's visibility, and negotiated links to government authorities in the Junta de Castilla y León to obtain funding for research. They also work as consultants with local government on issues of interest to the Women's Commission, and maintain an Observatory on Violence against Women (Martínez, 2017). Finally, they are forming inter-institutional networks in Spain, like the one attempted by Josefina Cuesta.

Their contributions seem to bring them closer to history, law, education and philosophy, but there are also approaches to studies of women's human rights. We see, perhaps, more reticence to deal with topics like women's reproductive and sexual rights, and a certain indifference towards social and labour-related issues. Their inter-generational discussions reveal marked divergences with younger, highly-orthodox women who are less open to dialogue, sustain slogans that are not up for debate, and lack analytical depth in their research projects, as could be observed in some sessions at Cemusa's Research Seminar.

\section{CONCLUSIONS}

As is the case in all academic and social groups, the historical process that led to the formation of Cemusa displays the contradictions, tensions, agreements and disagreements, ruptures, and difficulties inherent to consolidation. This was made more complex by the difficulties visible in the field of women's rights and the epistemological constructions of the relations between men and women that so closely touch the subjects/objects of study (López de la Vieja, 2012). These female scholars need to create better leaderships to bring the topics related to equality that concern professors, students and personnel to the university's discussion tables. Women must learn to negotiate pacts with a clear understanding of what they are agreeing to, while ensuring that their own non-aggression accord will allow them to advance in their goal of achieving an intergenerational dialogue that propitiates continuity.

With an insufficient budget and no adequate physical space for its academic personnel, Cemusa's very survival is threatened, though gender studies in graduate school have been revitalized. Perhaps women's studies centres will assume other academic guises in the university, such as new tools for negotiating, power and recognition of women professors. Such centres - under this or some other name, like gender research programs, centres or institutes- have been the institutional referents for women's and gender studies in universities worldwide, but have been denied the autonomy and financial and human resources necessary to compete institutionally for recognition by their peers.

The achievements made to date through feminist action are significant, but insufficient, and prospects seem to augur stagnation -or regressions?- on the path to equality between men and women, for we detect a resignifying of traditional feminine activities in the framework of globalization (Ávila, 2015a:15). 
Women's contributions to the society of knowledge ${ }^{21}$ are evident in both production and teaching, but the scenarios where power is exercised in universities have maintained the masculine tradition in a neo-patriarchal system in which the history of the Centre for Women's Studies is barely a fifteen-year spark in the immensity of 800 years of history at the ancient, still prestigious University of Salamanca.

\section{ACKNOWLEDGMENT}

The author thanks the Dirección General de Asuntos del Personal Académico of the Universidad Nacional Autónoma de Mexico for financing this research.

\section{NOTES}

1 Salmantina is the word used referring to a woman native to Salamanca.

2 Díez Balda (2002) "El movimiento feminista en Salamanca después de la muerte de Franco" in Revista de estudios, Salamanca. https://mujeresenred.net/IMG/pdf/ArticuloFem.pdf

3 Interviews by the author with María de los Ángeles Corrochano Cosmea, nurse, housewife, mother of three, militant of the Communist Party and the Asociación de Vecinos del Barrio de Garrido; member of the Coordinadora de Asociaciones de Vecinos de Salamanca, and founder of the Asamblea de Mujeres; June-November 2017, Salamanca.

4 Angeles, another female university professor and militant, defined Nines in her poem Risa blanca: "Angelines, innocent laugh, shade, sun, and a flowerpot with white albahaca... The careful years and commitments acquired from original sin agitate in her soul an uncertain rebelliousness... finally submission is transformed into the harsh dawning of liberation without liberty... a new woman in the blue robe of Insalud..."

5 "El derecho de la mujer al trabajo como reivindicación feminista" (ca. 1979) typescript.

6 These demands by underdeveloped nations were also common in Latin America.

7 La Asamblea de Mujeres began the practice of communicating with feminist, communitarian and university organizations through radio programs

8 This interview requested that her name be withheld.

9 Interview by the author with Soledad Murillo de la Vega, professor, University of Salamanca, and member of the Cemusa, Salamanca, August 2017

10 Her doctoral thesis (1986) El complejo esquisto-grauváquico, las series paleozoicas y la estructura hercinica al sur de Salamanca. Ediciones de la Universidad de Salamanca.

11 Her doctoral thesis (1996) El mito de la vida privada. De la entrega del tiempo propio.

12 Cemusa's official webpage states that the Seminar began in 1997, but the founder, Soledad Murillo, clarified that it was 1995.

13 Estatutos de la Universidad de Salamanca, at http://salade prensa.usal.es/filessp/P05_Informe_Unidad_de_igualdad_ CL 20160601.pdf; accessed 10 November $201 \overline{7}$.

14 "Reglamento de institutos de investigación, centros propios, grupos de investigación y unidades de excelencia", Título segundo, pp. 10-14; accessed at https://secretaria.usal.es/gesdoc/ files/8562-Reglamento_Institutos_Universitarios.pdf, $25 \mathrm{Au}$ gust 2017.

15 Cemusa's webpage expresses esteem for the first Director. See the tribute book by Martínez Quinteiro, Esther, et al., in the Bibliography.

16 Article 26 of the ascription and dismissals of this Reglamento states that: "The registration of personnel must indicate that the linkage of those ascribed to a Department will be partial and without demerit of the commitments with it... No one may belong to two Centers or to one Center and one Institute".

17 The term, 'society of knowledge' occupies a key place in current discussions in the Social Sciences and European politics. It is a concept that, apparently, summarizes the social transformations that are being generated in modern society, and serves to analyze these transformations. It also offers a vision of the future to normatively guide political action.

18 See the "Manifiesto X Encuentro de unidades de igualdad de las universidades españolas". https://www.urjc.es/zh/todas-las-noticias-de-actualidad/2562-manifiesto-del-x-encuentro-delas-unidades-de-igualdad-de-las-universidades-espanolas

19 See the publications cited on the Center's webpage: http://mujeres.usal.es/index.php?option $=$ com content $\&$ task $=$ view\&id $=1$ $97 \&$ Itemid $=104$. This collection is held in the Biblioteca Universitaria de Santa María de los Ángeles.

20 Interview with the founder of the Partido Feminista Español, Salamanca, April 2017.

21 A document from the Universidad National Autónoma de México affirms that "A society of knowledge must be able to integrate each one of its members and promote new forms of solidarity with current and future generations". In this sense, the construction of knowledge on women and its transmission through teaching and diffusion in the public and private life of social groups and people is a feminist contribution that proposes better co-existence between men and women. http:/uiap. dgenp.unam.mx/apoyo_pedagogico/proforni/antologias/ UNESCO $\% 20$ sociedades $\% 20$ del $\% 20$ conocimiento.pdf; accessed 20 October 2017.

\section{REFERENCES}

Ávila, Virginia (2015) "Miradas de mujer. Las tendencias actuales de los estudios feministas en México. In Cuesta, Josefina, De Prado, María Luz y Rodríguez, Francisco J. ¿Mujeres sabias? Mujeres universitarias en España y América Latina. Limoges, Pulim: 477-495.

Ávila, Virginia; Suárez, Paola (2015a) Los estudios de género hoy. Debates y perspectivas, México, Universidad Nacional Autónoma de México. Facultad de Filosofía y Letras y Dirección General de Asuntos del Personal Académico.

Ávila, Virginia; Suárez, Ariadna Otaiti (2012) "Las feministas mexicanas: mujeres guerreras subversoras del orden" en Virginia Ávila García y Paola Suárez, Entre mujeres te veas. Las académicas y los estudios feministas en México, Argentina, Venezuela y España. México. Palabra de Clío: 15-42.

Borderías, Cristina (ed) (2009). La historia de las mujeres: perspectivas actuales. Barcelona. Icaria.

Certeau, Michel de (1993) La escritura de la historia. México. Universidad Iberoamericana.

Díez, Antonia (1986) El complejo esquisto-grauváquico, las series paleozoicas y la estructura hercínica al sur de Salamanca. Salamanca. Ediciones de la Universidad de Salamanca

Díez, Antonia (2002) "El movimiento feminista en Salamanca, después de la muerte de Franco". Revista de Estudios. Salamanca: $243-285$.

Estatutos de la Universidad de Salamanca, http://www.usal.es/files/ estatutos.pdf. Consultado, 26 de junio de 2017

Folguera, Pilar (2006) "Voces del feminismo" en Morant, Isabel (dir) (2006) G. Gómez-Ferrer, G. Cano, D. Barrancos y A. Lavrin, Historia de las mujeres de España y América Latina, vol 4. Madrid. Cátedra: 433-434

Flecha, Consuelo (2014) "Desequilibrios de género en educación en la España contemporánea: causas, indicadores y consecuencias". In Revista Internacional de Ciencias Sociales, no. 33: 4960.

Francia, Ignacio (2002) Salamanca 1950-1992. Materiales para la historia. Salamanca. Caja Duero.

Krüger, Karsten (2006) "El concepto de la sociedad del conocimiento" en Biblio3w. Revista bibliográfica de Geografía y 
Ciencias Sociales, Universidad de Barcelona, vol. XI, no. 683: 293-318, en http://www.ub.edu/geocrit/b3w-683.htm

López de la Vieja, Teresa (2012) "Construir la igualdad". In Perdomo, I., Puyol, L. Género, conocimiento e igualdad. Madrid. Plaza y Valdés: 47-55.

López de la Vieja, Teresa, Barrios, Olga, Figueruelo Ángela, Velayos, Carmen y Carbajo, Judith (editoras) (2006) Bioética y feminismo. Salamanca. Ediciones de la Universidad de Salamanca.

Martínez, Esther; Figueruelo, Ángela; López de la Vieja, Teresa; Barrios, Olga; Velayos, Carmen, Calvo, $\mathrm{M}^{\mathrm{a}}$ Dolores (eds) (2007) La Igualdad como compromiso: estudios de género en homenaje a la profesora Ana Díaz Medina. Salamanca, Universidad de Salamanca.

"Memoria. Proceso de creación/adscripción de institutos universitarios de investigación" (2015) Cemusa.

Murillo, Soledad (1993) "La división sexual de los espacios público, privado y doméstico", Tesis de doctorado en Sociología, Universidad Complutense de Madrid.

Murillo, Soledad (1996) El mito de la vida privada. De la entrega del tiempo propio. $2^{\text {a }}$. Ed. Madrid. Siglo XXI.

Pavón, Armando (2017) "La universidad masculina: La Real Universidad de México en la época colonial". In Ávila García, Virginia y Suárez Paola, América globalizada. Reinterpreta- ciones de las relaciones de género, desafios y alternativas. México. Universidad Nacional Autónoma de México y Editorial Eón.

Tavera, Susana (2006) "Mujeres en el discurso franquista hasta los años sesenta". In Morant, Isabel (dir) Gómez-Ferrer, G. Cano, D. Barrancos y A. Lavrin(coords) Historia de las mujeres de España y América Latina, vol 4. Madrid. Cátedra: 239-265

Valcárcel, Amelia (2006) Treinta años de feminismo en España" en Morant, Isabel (dir) (2006) Gómez-Ferrer, G. Cano, D. Barrancos y A. Lavrin (coords). Historia de las mujeres de España y América Latina, vol 4. Madrid. Cátedra.

\section{INTERVIEWS}

Josefina Cuesta Bustillo. Ex-Director, Centro de Estudios de la Mujer (Cemusa)

María Antonia Díez Balda. Professor and activist

María de los Angeles Corrochano Cosmea. Communist and militant feminist

Lidia Falcón. Militant and founder of The Feminist Party

María Esther Martínez Quinteiro. Ex-Director of Cemusa

Soledad Murillo de la Vega. Sociology professor

Mercedes Romero. Professor 